\title{
Avaliação do efeito antitumoral da vanilina e divanilina em células de osteossarcoma murino
}

\section{RESUMO}

O osteossarcoma é o tumor maligno primário mais comum do tecido ósseo e acomete principalmente crianças e adolescentes. Está associado a altas taxas de mortalidade, com etiologia pouco conhecida; sendo assim, estudos que envolvem conhecimentos acerca do tema se fazem necessários. A vanilina, o principal composto obtido do extrato natural da baunilha tem demonstrado, em diversas pesquisas, possuir propriedades antitumorais, assim como o seu dímero, chamado divanilina. $\mathrm{O}$ uso de compostos naturais para o tratamento da doença tem se tornado uma alternativa promissora, principalmente como agentes adjuvantes. $O$ artigo 1 teve como principal objetivo reunir, por meio de uma revisão sistemática da literatura, plantas provenientes do bioma Cerrado brasileiro que possuem efeitos contra células tumorais. Foram identificadas 39 espécies no total e informações como composto majoritário e modo de ação nas células tumorais foram incluídas. $\mathrm{O}$ artigo 2 teve como objetivo avaliar as propriedades antitumorais dos compostos vanilina e divanilina em células ósseas tumorais murinas. Para isso, as linhagens de células ósseas normal (MC3T3-E1) e tumoral (UMR-106) foram cultivadas e mantidas em condições apropriadas para o estudo in vitro. Foram avaliados o efeito dos compostos vanilina e divanilina na viabilidade celular das linhagens normal e tumoral e formação de colônias, migração, produção de espécies reativas de oxigênio (EROs) nas células tumorais, além da análise proteômica. Ambos os compostos mostraram exercer efeitos na viabilidade celular das linhagens normal e tumoral e diminuir a formação de colônias. O composto vanilina foi capaz de inibir o processo de migração e a divanilina diminuiu a produção de EROs. Quanto à análise proteômica, ambos os compostos mostraram agir sobre a expressão de importantes proteínas envolvidas na progressão tumoral. Nossos resultados sugerem que os compostos vanilina e divanilina possuem propriedades contra células ósseas tumorais murinas. $\mathrm{O}$ uso destes poderia ser 
uma alternativa promissora para o tratamento adjuvante do câncer ósseo, no entanto, necessitando de mais estudos.

Palavras-chave: Osteossarcoma. Vanilina. Divanilina. 